\title{
REKAYASA MEDIA PEMBELAJARAN FISIKA BERBASIS WEBSITE UNTUK SISWA KELAS X SMA NEGERI I GUBUG POKOK BAHASAN GERAK LURUS
}

\author{
Denny Rachmadi \\ Praktisi Pendidikan Sekolah Menengah Atas Kabupaten \\ Grobogan
}

\begin{abstract}
Abstrak
Rendahnya hasil belajar siswa dalam pembelajaran fisika mendorong keinginan guru untuk memperbaiki model pembelajaran fisika agar mendapatkan hasil belajar yang sesuai dengan harapan. Dalam materi fisika dibutuhkan adanya kemampuan siswa untuk berabstraksi dalam memahai konsep fisika. Hal ini dapat di atasi dengan adanya praktikum fisika, itu kalau fasilitas laboratorium fisika lengkap. Untuk mengatasi kekurangan sarana laboratorium fisika dapat digunakan media computer untuk menampilkan konsep fisika yang abstrak menjadi nyata baik dalam bentuk film atau animasi. Selain itu adanya kegiatan guru dan kelembagaan mengurangi jumlah tatap muka dalam pembelajaran fisika. Dengan demikian dibutuhkan media pembelajaran fisika yang berbasis website agar siswa dapat belajar.
\end{abstract}


Yang menjadi masalah dalam penelitian ini media pembelajaran computer yang berbasis website yang bagaimana yang akan diciptakan dan yang dapat dimanfaatkan untuk meningkatan hasil belajar fisika kelas X SMA Negeri 1 Gubug.

Untuk mengetahui layak ataupun tidak layak penggunaan media pembelajaran fisika menggunakan media komputer berbasis website tersebut perlu adanya uji instrument. Uji kelayakan instrument dalam penelitian ini menggunakan white box dan black box. Selain itu juga dilakukan uji respon user dan hasil belajar siswa terhadap pemakaian instrument ini menggunakan angket (kuisioner) dengan metode membandingan instrument ini dengan instrument lain yang ada di SMA N I Gubug.

Dari hasil uji whitebox dan blackbox tidak ada masalah dan program dapat berjalan dengan baik. Dari uji respon user menggunakan angket diperoleh data dan analisis data menyatakan bahwa $80 \%$ respon user memiliki kecenderungan yang tinggi dan 13,3\%7 dalam kategori cukup untuk menyukai media pembelajaran fisika berbasis web dari pada instrument lain yang hanya 23,33\% dalam kategori cukup dan $66,67 \%$ pada kategori rendah. Selain itu dari uji hasil belajar siswa menggunakan tes hasil belajar fisika diperoleh data dan analisis data menyatakan bahwa $63,33 \%$ respon user memiliki kecenderungan yang tinggi dan $30 \%$ dalam kategori cukup dan sisanya rendah untuk menyukai media pembelajaran fisika berbasis web daripada instrument lain yang hanya 6,67\% kategori tinggi dan $23,33 \%$ dalam kategori cukup dan $66,67 \%$ pada kategori rendah sisanya rendah. Selain itu pada uji-t pada respon user diperoleh hasil bahwa thitung (16,1) lebih besar dari $\mathrm{t}$ table (1,67), ini menunjukkan media pembelajaran fisika berbasis web lebih baik dari media pembelajaran lain ( film ) dilihat dari respon user dan dari hasil belajar diperoleh hasil bahwa thitung $(4,271)$ lebih besar dari t table $(1,67)$, 
ini menunjukkan media pembelajaran fisika berbasis web lebih baik dari media pembelajaran lain ( film) dilihat dari hasil belajar siswa.

Dari penelitian diperoleh hasil berupa media pembelajaran fisika berbasis web yang layak digunakan.

Kata kunci: instrument pembelajaran fisika berbasis website, respon siswa (user) hasil belajar fisika.

\section{LATAR BELAKANG}

Dalam proses pembelajaran di kelas, tidak semua peserta didik mempunyai kemampuan yang sama. Hal ini akan menyebabkan adanya perbedaan hasil yang diperoleh siswa dalam mengikuti proses pembelajaran. Bagi siswa yang memiliki kemampuan lebih akan memperoleh hasil yang baik dibandingkan dengan siswa yang memiliki kemampuan rendah. Seorang guru tidak mungkin dapat memberikan perlakuan yang berbeda-beda pada saat melaksanakan proses pembelajaran di kelas. Dengan demikian dapat terjadi perbedaan hasil yang diperoleh siswa setelah pembelajaran selesai. Hal ini terjadi juga pada SMA Negeri 1 Gubug dimana masih ada siswa yang belum berhasil mencapai kriteria ketuntasan minimal (KKM) hasil belajar yang ditetapkan oleh pihak lembaga. Berdasakan hasil analisa ujian semester ganjil 2008 / 2009 diperoleh data bahwa siswa kelas X SMA N I Gubug banyak yang salah dalam mengerjakan konsep yang ada kaitannya dengan konsep gerak khususnya GLBB 50persen tidak dapat dikerjakan siswa dan tidak memenui KKM yang telah ditentukan oleh guru.

Menurut Dorries pembelajaran berbantukan multimedia sebagai salah satu media pembelajaran dapat digunakan untuk memenuhi keperluan pelajar yang berbeda dari segi keupayaan, intelegensi dan gaya pembelajaran. Pembelajaran individu mer- 
upakan salah satu sistem dari berbagai dan prosedur pembelajaran yang fleksibel dimana peserta didik diberikan tanggung jawab untuk merancang dan melaksanakan pembelajaran mereka. [7]

Web pembelajaran interaktif membuat pelajar boleh memilih waktu, isi serta tujuan pembelajaran dengan lebih cepat, hal ini karena program website pembelajaran ini memberi peluang serta kebebasan kepada pelajar untuk memilih apa yang digemari dari setiap kemampuan individu. Peserta didik juga berpeluang belajar dengan pelajaran yang susah secara berulang kali sehingga pemahaman dapat dicapai.

Namun implementasi pembelajaran fisika berbasis web yang ada masih muncul adanya kendala dalam pembelajaran, artinya masih ada sisi-sisi yang belum tersoroti oleh webmaker. Berikut ini kajian beberapa web fisika yang diamati penulis.

\begin{tabular}{|c|c|c|c|c|c|c|c|c|}
\hline \multirow{2}{*}{$\begin{array}{l}\text { Situs E-learn- } \\
\text { ing }\end{array}$} & \multirow{2}{*}{$\begin{array}{l}\text { Tujuan } \\
\text { Pembe- } \\
\text { lajaran }\end{array}$} & \multicolumn{3}{|c|}{$\begin{array}{c}\text { Sumber } \\
\text { Materi }\end{array}$} & \multicolumn{3}{|c|}{ Feedback } & \multirow{2}{*}{$\begin{array}{c}\text { Ke- } \\
\text { mandirian/ } \\
\text { interaktif }\end{array}$} \\
\hline & & $\overrightarrow{\vec{x}}$ & 寻 & 总. & $\begin{array}{l}\mathscr{2} \\
\stackrel{2}{0}\end{array}$ & 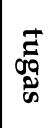 & ㄹ. 율. & \\
\hline $\begin{array}{l}\text { www.fisikaf- } \\
\text { isifu.sch.id }\end{array}$ & $\mathrm{V}$ & V & $x$ & $x$ & $\mathrm{v}$ & $x$ & $x$ & kurang \\
\hline $\begin{array}{c}\text { http:/ / fisika. } \\
\text { name }\end{array}$ & $\mathrm{v}$ & V & $x$ & $x$ & $x$ & $x$ & $x$ & kurang \\
\hline $\begin{array}{l}\text { www.elearn- } \\
\text { ing-smk2.sch.id }\end{array}$ & $\mathrm{v}$ & $\mathrm{V}$ & $x$ & $x$ & $\mathrm{v}$ & $\mathrm{v}$ & $x$ & kurang \\
\hline $\begin{array}{c}\text { www.turino. } \\
\text { web.id }\end{array}$ & $\mathrm{V}$ & $\mathrm{V}$ & $x$ & $x$ & $\mathrm{v}$ & $x$ & $\mathrm{v}$ & kurang \\
\hline
\end{tabular}

Berdasarkan media web fisika yang telah ada masih terdapat kekurangan daya interaktifitas siswa dan umpan balik siswa sehingga mendorong penulis untuk membuat media web pembelajaran fisika yang memiliki daya interaktif yang mem- 
buat siswa lebih mandiri dan siswa dapat mengukur kemampuannya.

\section{RUMUSAN MASALAH}

\section{a. Pengguna}

1) Pencapaian hasil belajar kurang maksimal, dan komunikatif

2) Interaksi, kemandirian dan feedback serta kontrol juga bimbingan belajar kurang.

\section{b. Iptek}

1) Web pembelajaran fisika yang ada kurang memenuhi kriteria media pembelajaran yang meliputi; tujuan pembelajaran, materi belajar, feedback dalam belajar, dan mandiri (tanpa bantuan orang ).

\section{TUJUAN PENELITIAN}

Berdasarkan permasalahan diatas mendorong penulis untuk mewujudkan media pembelajaran yang;

1. dapat meningkatkan interaktivitas belajar siswa dan kemandirian dalam proses belajar sehingga hasil belajar fisika pokok bahasan gerak lurus pada siswa kelas X SMA N I Gubug meningkat,memberi kemudahan pada guru mengontrol dan membimbing kegiatan belajar siswa siswa SMA Negeri I Gubug kelas $X$.

2. menarik dan memenuhi kriteria pembelajaran meliputi; tujuan pembelajaran, materi belajar, feedback,dan mandiri (tanpa bantuan orang lain ).

\section{MANFAAT PENELITIAN}

Manfaat yang diharapkan dari pencapaian tujuan hasil penelitian ini adalah sebagai berikut :

\section{Bagi Pengguna :}

1. Meningkatkan interaktivitas belajar siswa sehingga siswa dapat mandiri dalam proses belajar

2. Meningkatkan kesempatan bimbingan dan control belajar siswa. 


\section{Bagi IPTEK :}

1. Mengoptimalkan kreatifitas sistem pembelajaran menggunakan web design yang mengandung unsur-unsur kompetensi, strategi, materi pembelajaran berupa tutorial, pengayaan pengetahuan \& belajar dan system evaluasi serta report hasil belajar siswa.

2. Dapat meningkatkan daya tarik web pembelajaran fisika bagi siswa dan memberikan pelayanan kepada siswa untuk belajar mandiri.

\section{LANDASAN TEORI}

Dick \& Carey menyatakan bahwa strategi pembelajaran menjelaskan komponen-komponen umum dari prosedur suatu set bahan pembelajaran yang akan digunakan untuk mencapai hasil yang diinginkan. Sependapat dengan definisi Dick dan Carey, Suparman mengatakan strategi pembelajaran terdiri dari empat komponen utama, yaitu: Urutan Kegiatan Pembelajaran, Metode Pembelajaran, Media Pembelajaran, Waktu. Kemudian Gerlach dan Elly juga mengatakan bahwa Strategi pembelajaran merupakan cara-cara yang dipilih untuk menyampaikan materi pelajaran dalam lingkungan pengajaran tertentu yang terdiri dari urutan kegiatan, metode, dan prosedur yang dapat memberikan pengalaman belajar kepada siswa untuk mencapai tujuan belajar. [9]

Manfaat e-learning Menurut Soekartawi (dalam Siahaan) beberapa manfaat yang diperoleh guru adalah bahwa guru dapat : (1) lebih mudah melakukan pemutakhiran bahan-bahan yang menjadi tanggung jawabnya sesuai dengan tuntutan perkembangan keilmuan yang terjadi, (2) mengembangkan diri atau melakukan penelitian guna peningkatan wawasannya karena waktu luang yang dimiliki realtif lebih banyak, (3) mengontrol kegiatan belajar peserta didik. Bahkan guru juga dapat mengetahui kapan peserta didiknya belajar, topik apa yang dipelajari, berapa lama sesuatu topik dipelajari, serta berapa kali topik tertentu dipelajari ulang, (4) mengecek apakah peserta didik telah mengerjakan soal-soal latihan setelah mempelajari topik terten- 
tu, dan (5) memeriksa jawaban peserta didik dan memberitahukan hasilnya kepada peserta didik.

Beberapa hal yang perlu dilakukan untuk mengukur kualitas sebuah web menurut Adi Sumaryadi [7] antara lain :

1. General Appearance, secara umum kita harus melihat tampilan dari website mulai dari desain, tata letak serta kemudahan navigasi. Desain yang bagus bisa dilihat dari kenyamanan pengunjung seperti warna tidak terlalu mencolok, nyaman dilihat, kekontrasan juga pelru diperhatikan, website yang bagus tidak terlalu gelap dan juga tidak terlalu terang. Tata letak atau blok-blok konten juga harus kita perhatikan, misalkan informasi penting seharusnya disimpan di atas, menu yanh mudah diakses oleh pengunjung dan juga lebar halaman website itu sendiri, web yang bagus sudah memperhitungkan kemungkinan-kemungkinan ukuran resolusi monitor sehingga pengunjung tidak banyak menggunakan scrollbar untuk melihat halaman itu. Kemudahan navigasi juga harus diperhatikan dalam tampilan umum, kecenderungan pengunjung akan dibuat bingung ketika terlalu banyak navigasi yang tidak menentu. URL yang digunakan mudah atau tidak digunakan. Kemudahan URL untuk dibaca tidak hanya mempermudah pengunjung untuk mengingat URL tadi, melainkan banyak crawler dari mesin pencari yang memanfaatkan kemudahan pembaca URL.

2. Ease of Use, kemudahan penggunaan semua elemen yang ada dalam website menjadi salah satu faktor kunci dalam mengevaluasi sebuah halaman web.

3. Browser Compatibility, website yang bagus seharusnya sudah dicoba di semua kemungkinan browser yang digunakan. Kompabilitas terhadap semua browser sangat menentukan kualitas website. Sebuah website yang dibangun harus bagus ketika diakses di Internet Explorer, Opera, Mozilla Firefox, Safari bahkan link sekalipun.

4. Purpose, beberapa pertanyaan yang dapat diajukan antara lain : website mengandung tujuan utama, ada keterhubungan antara topic dan topic lainnya, halaman web dapat di- 
turunkan ke dalam halaman-halaman lain yang merupakan subtopiknya, website mempunyai konten yang bagus, dan ada keterkaitan antara konten yang ada dengan topic yang dibangun.

5. Author, kemudahan untuk mendapatkan informasi tentang pengelola atau pembuat situs itu menjadi salah satu faktor utama.

6. Link Validation, selain kemudahan untuk menavigasi dan kemudahan pembacaan URL, validasi link juga harus diperhatikan. Semua link yang ada harus dapat dikunjungi dengan website, baik link internal dalam sebuah halaman (anchor), link antar halaman hingga link yang berhubungan dengan website orang lain. Semua link yang ada harus menghindari beberapa kriteria seperti di bawah ini

a. HTTP errors, hal yang semacam ini disebabkan oleh kesalahan konfigurasi webserver, not found, pesan seperti ini muncul ketika file yang dituju tidak ada

b. URLs not followed, menunjukkan URL yang diberikan tidak bisa dibuka

c. URLs timed out, menunjukkan ada link yang berat ketika diakses

d. Unreachable URLs, menunjukkan ada link yang hanya sebagian dapat diakses atau tidak sempurna.

7. Stability, kesetabilan sebuah website mejadi faktor utama juga dalam mengevaluasi sebuah website.

Menurut Prof. Atwi Suparman (Rektor UT) di dalam Muhammad Rusli Sofyan(2005) ${ }^{[7]}$, model desain pembelajaran menggunakan Dick and Carey Systems Approach Model sangat tepat digunakan untuk sistem pembelajaran yang melibatkan komputer dalam proses pembelajaran. 


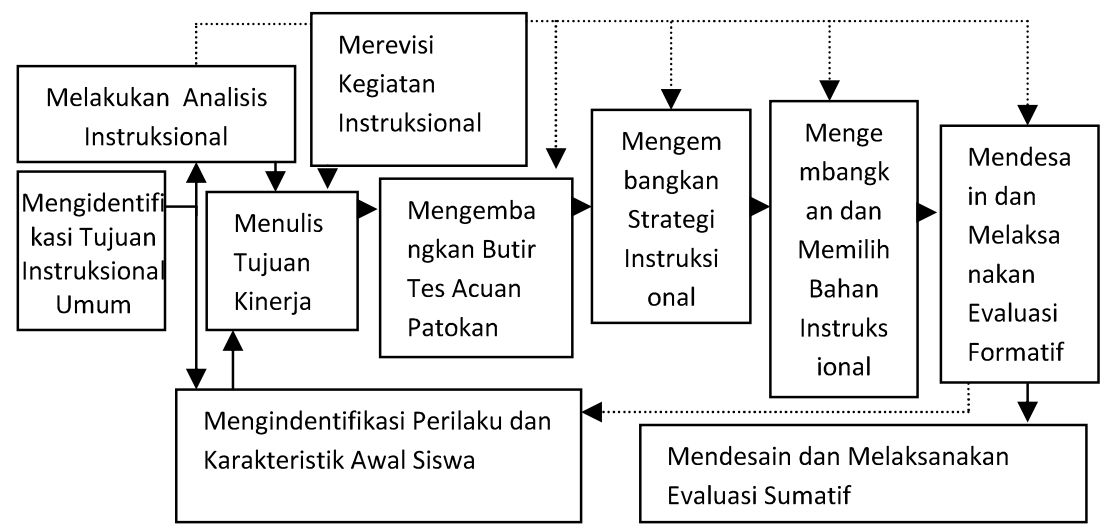

Gambar 1. Desain Pembelajaran Dick

Unified Modellnng Language (UML) adalah sebuah bahasa yang telah menjadi standar dalam industri untuk visualisasi, merancang dan mendokumentasikan sistem piranti lunak. Dengan menggunakan UML kita dapat membuat model untuk semua jenis aplikasi piranti lunak, dimana aplikasi tersebut dapat berjalan pada piranti keras, sistem operasi dan jaringan apapun, serta ditulis dalam bahasa pemrograman apapun..$^{[9]}$

Beberapa diagram UML yang dapat dipilih sebagai standar dalam dalam membangun suatu sistem adalah sebagai berikut:
a. Use Case Diagram
e. Sequence Diagram
b. Class Diagram
f. Collaboration Diagram
c. Statechart Diagram
g. Component Diagram
d. Activity Diagram
h. Deployment Diagram

Ada banyak teknik pendekatan pengujian yang dapat digunakan untuk menguji sistem perangkat lunak, diantaranya sebagai berikut :

1. Pendekatan white-box testing

Pengujian white-box berfokus pada struktur kontrol program. Test case dilakukan untuk memastikan bahwa semua statemen pada program telah dieksekusi paling tidak satu kali selama pengujian dan bahwa semua kondisi logis telah diuji. 
2. Pendekatan black-box testing

Pengujian black-box berfokus pada domain informasi dari perangkat lunak. Test case dilakukan dengan mempartisi domain input dari suatu program yang dapat memberikan domain informasi yang diharapkan dengan benar.

\section{METODE PENELITIAN}

\section{Metode Rekayasa}

Metode penelitian yang digunakan dalam membangun media pembelajaran fisika menggunakan komputer berbasis website ini menggunakan pendekatan penelitian rekayasa foward engineering yaitu rekayasa yang dilakukan dari perencanaan, perancangan, pembangunan dan penerapan yang merupakan bentuk tahapan untuk mencapai tujuan pendidikan.

\section{Analisis Kebutuhan}

Tahapan ini dilakukan dengan mendeskripsikan kebutuhan yang diperlukan untuk membangun media pembelajaran fisika menggunakan komputer berbasis website yang dilakukan dengan cara :

Mengadakan pengamatan secara langsung terhadap masalah belajar siswa dan membandingkan beberapa produk media pembelajaran yang telah ada. Adapun permasalahannya sebagai berikut; Pencapaian hasil belajar kurang maksimal, interaktivitas dan kemandirian belajar rendah, tidak ada kontrol dan bimbingan belajar siswa dan konten web pembelajaran fisika yang kurang menarik dan memenuhi kriteria pembelajaran meliputi; tujuan, pembelajaran, materi, feedback dan mandiri.

\section{Perancangan}

Tahapan ini meliputi 2 tahap langkah yaitu sebagai berikut:

a. Menganalisis tujuan pembelajaran, materi belajar, model evaluasi, karakteristik media yang digunakan dan managemen konten web serta sub-sub menu.

b. Mendesain tujuan pembelajaran, unit-unit materi, model evaluasi, daftar nilai, strategi/skenario pembela- 
jaran, desain antarmuka, mendesain menu navigator, dan managemen database.

\section{Pembangunan}

Tahapan yang dilakukan adalah mengatur unit dan model materi belajar, soal evaluasi, mengatur pola pembelajaran dan tahapan belajar dilanjutkan dengan pengkodean program yang telah dirancang sebelumnya, serta fitur pemeliharaan.

\section{Penerapan}

Pada tahapan ini kode program yang telah terbentuk menjadi e-learning diimplementasikan sesuai dengan desain dan skenario yang telah ditentukan. Jika ada yang belum sesuai arsitektur harus diperbaiki.

\section{Pengujian}

Pengujian yang dilakukan pada media ini adalah kesesuaian materi, soal dan pertimbangan dengan pakar. Untuk pengujian pada rekayasa media pembelajaran fisika menggunakan website ini dilakukan white box testing dan black box testing. Selain itu juga ada uji responden yaitu hasil belajar dan questioner tentang konten web yang meliputi tujuan, pembelajaran, materi, feedback dan mandiri.

Tahapan-tahapan ini dapat dilakukan secara overlap dan bersiklus.

a. Metode Uji Implementasi

Setelah e-learning berhasil diimplementasikan dan dilakukan pengujian terhadap hasil rekayasa sistem, maka selanjutnya dilakukan uji implementasi dalam penggunaanya kepada responden. Tahapan yang dilakukan adalah sebagai berikut :

- Pengujian Respon User Terhadap Sistem

- Pengujian Terhadap Keberhasilan Responden

- Analisis Hasil Tes 


\section{KERANGKA PEMIKIRAN}

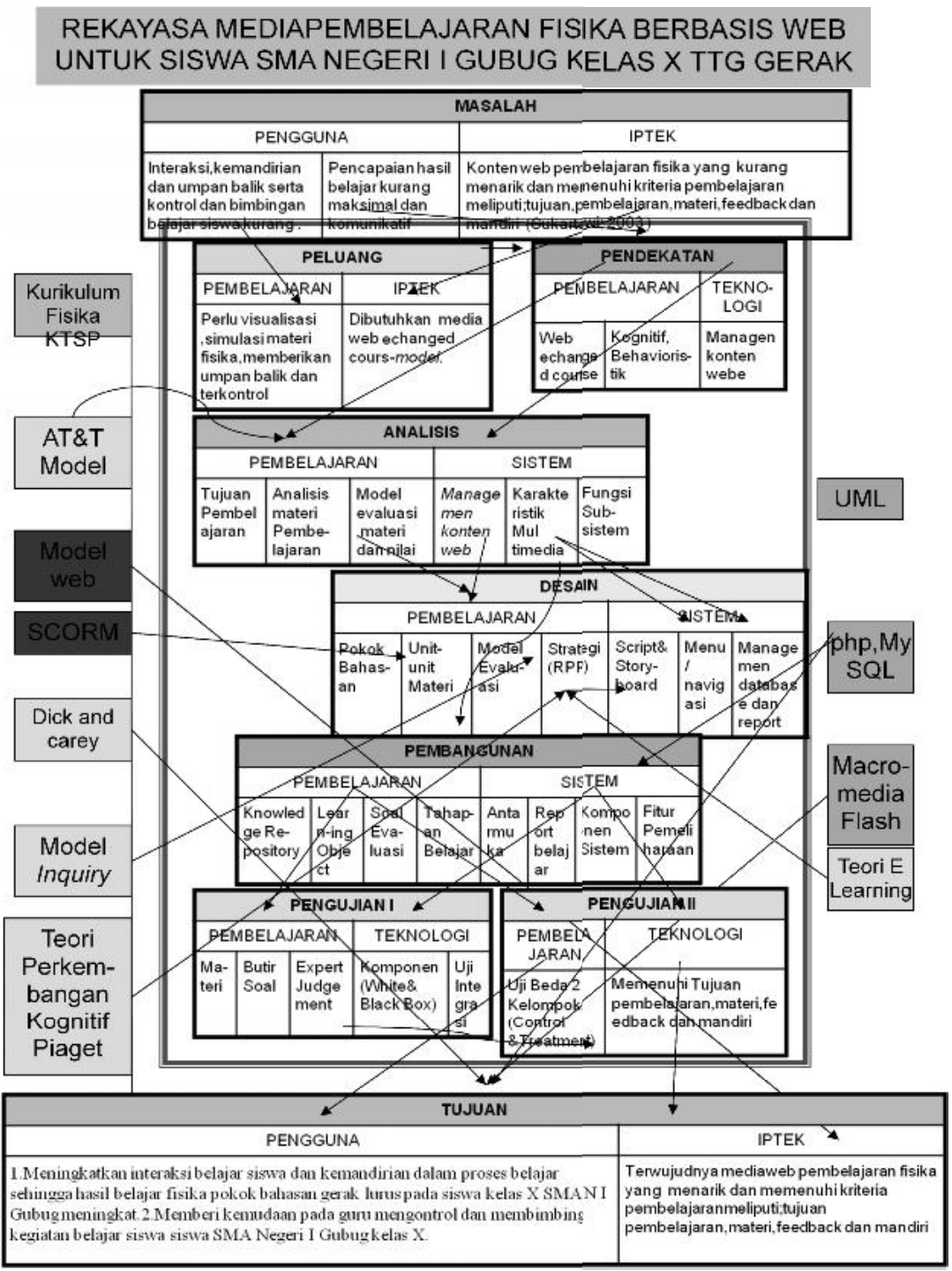

\section{PEMBAHASAN DAN HASIL PENELITIAN}

Identifikasi kebutuhan (requirement) merupakan kebutuhan yang ditentukan oleh pengguna atau pemilik sistem. Kebutuhan ini dibagi menjadi 2 bagian yaitu functional requirement dan 
nonfunctional requirement. Functional requirement merupakan spesifikasi hal-hal yang harus dilakukan oleh sebuah sistem, dan nonfunctional requirement merupakan properti atau kualitas yang harus dimiliki sebuah sistem.

Dari sistem e-learning yang akan dibuat didefinisikan bentuk functional requirement sebagai berikut:

Tabel 1. Tabel Functional Requirement

\section{FUNCTIONAL REQUIREMENT}

1. Sistem dapat menyajikan informasi tujuan pembelajaran yang dapat diakses oleh guru dan siswa

2. Sistem dapat menyajikan informasi materi pembelajaran yang dapat diakses oleh guru dan siswa

3. Sistem dapat menyajikan soal evaluasi yang dapat dikerjakan oleh siswa

4. Sistem dapat menyajikan nilai hasil evaluasi siswa

5. Sistem dapat menyediakan fasilitas pengisian, pengeditan dan penghapusan soal evaluasi yang dilakukan oleh guru.

6. Sistem dapat menyediakan fasilitas konsultasi antara siswa dan guru

7. Sistem dapat menyediakan fasilitas pemberian dan pengiriman tugas

8. Sistem menyediakan fasilitas pengaksesan menggunakan login khusus untuk guru dan siswa.

Dari sistem e-learning yang akan dibuat didefinisikan bentuk non functional requirement sebagai berikut: 
Tabel 2. Tabel Non-Functional Requirement

\begin{tabular}{|c|c|}
\hline \multicolumn{2}{|c|}{ NON FUNCTIONAL REQUIREMENTS } \\
\hline Tipe Kebutuhan & Penjelasan \\
\hline Performance & 1. Memiliki response time yang cepat \\
\hline Information & $\begin{array}{l}\text { 1. Informasi yang ditampilkan akurat } \\
\text { dan sesuai kebutuhan } \\
\text { 2. Informasi dapat di-update sesuai ke- } \\
\text { butuhan }\end{array}$ \\
\hline Economy & $\begin{array}{l}\text { 1. Sistem dapat menekan biaya pembe- } \\
\text { lian buku dan pencetakan modul. } \\
\text { 2. Sistem dapat diakses kapan saja dan } \\
\text { dimana saja melalui komputer yang } \\
\text { terhubung jaringan. }\end{array}$ \\
\hline $\begin{array}{l}\text { Control and } \\
\text { Security }\end{array}$ & $\begin{array}{l}\text { 1. Sistem harus dapat melakukan kontrol } \\
\text { terhadap pengaksesan dengan adan- } \\
\text { ya login }\end{array}$ \\
\hline Efficiency & $\begin{array}{l}\text { 1. Penggunaan sistem dapat mendorong } \\
\text { efisiensi pemakaian kertas }\end{array}$ \\
\hline Service & $\begin{array}{l}\text { 1. Sistem berbasis Jaringan } \\
\text { 2. Sistem harus mudah digunakan (user } \\
\text { friendly) } \\
\text { 3. Dokumentasi pembuatan sistem yang } \\
\text { rapi dan terstruktur } \\
\text { 4. Sistem harus dapat meminimalisir } h u- \\
\text { man error }\end{array}$ \\
\hline
\end{tabular}

Dari media web pembelajaran fisika yang dibuat, dilakukan analisa hasil tes untuk menarik kesimpulan sejauh mana keberhasilan dan efektifitas media web pembelajaran fisika yang digunakan oleh siswa dalam meningkatkan pemahamannya pada proses pembelajaran. Analisis hasil tes yang digunakan adalah 
analisis statistik sederhana, yaitu dengan mengambil prosentase tingkat keberhasilan dan rata-ratanya terhadap nilai maksimum, sebagai berikut;

Dari uji respon user menggunakan angket diperoleh data dan analisis data menyatakan bahwa $80 \%$ respon user memiliki kecenderungan yang tinggi dan 13,3\%7 dalam kategori cukup untuk menyukai media pembelajaran fisika berbasis web dari pada instrument lain yang hanya $23,33 \%$ dalam kategori cukup dan $66,67 \%$ pada kategori rendah. Selain itu dari uji hasil belajar siswa menggunakan tes hasil belajar fisika diperoleh data dan analisis data menyatakan bahwa $63,33 \%$ respon user memiliki kecenderungan yang tinggi dan 30\% dalam kategori cukup dan sisanya rendah untuk menyukai media pembelajaran fisika berbasis web daripada instrument lain yang hanya 6,67\% kategori tinggi dan $23,33 \%$ dalam kategori cukup dan $66,67 \%$ pada kategori rendah sisanya rendah. Selain itu pada uji-t pada respon user diperoleh hasil bahwa $\mathrm{t}$ hitung $(16,1)$ lebih besar dari $\mathrm{t}$ table (1,67), ini menunjukkan media pembelajaran fisika berbasis web lebih baik dari media pembelajaran lain ( film ) dilihat dari respon user dan dari hasil belajar diperoleh hasil bahwa $t$ hitung $(4,271)$ lebih besar dari $t$ table $(1,67)$, ini menunjukkan media pembelajaran fisika berbasis web lebih baik dari media pembelajaran lain ( film) dilihat dari hasil belajar siswa.

\section{KESIMPULAN DAN SARAN}

Dari hasil penelitian dan evaluasi terhadap penggunaan software baru dapat disimpulkan bahwa sistem pembelajaran ini telah dilaksanakan dengan hasil baik, hal tersebut sesuai dengan :

1. Terwujudnya software media pembelajaran fisika berbasis website untuk siswa kelas X SMA Negeri I Gubug materi bahasan gerak lurus.

2. Media pembelajaran Fisika berbasis WEB ini telah memenuhi unsur-unsur pendidikan dan sudah memenuhi cakupan konten pembelajaran, meliputi: tujuan, materi dan bahan ajar, kurikulum, umpan balik, dan evaluasi, serta konsultasi 
3. Sistem ini memberikan kemudahan serta membantu siswa dalam penguasaan materi, sehingga siswa tidak perlu akan ketinggalan materi dan evaluasi untuk meningkatkan minat belajar siswa berdasar prosentase respon user sebesar $80 \%$ tergolong kategori tinggi.

4. Media pembelajaran fisika berbasis website lebih baik dari media pembelajaran lain (film) dilihat dari respond dan hasil belajar siswa materi gerak lurus.

Walaupun dari hasil pengujian menunjukkan sistem pembelajaran ini cukup layak dipergunakan, namun ada beberapa hal yang perlu penulis sarankan untuk perbaikan sistem ini.

Sistem pembelajaran ini bukan dimaksudkan sebagai pengganti kegiatan belajar mengajar dikelas, tetapi sebagai salah satu sumber belajar lain yang memenuhi unsur-unsur edukatif dan sekaligus sebagai bahan pengayaan atau remidial bagi siswa. 


\section{DAFTAR PUSTAKA}

Mayup,Afrizal.2005. E-learning Fisika Menggunakan Macromedia Flash MX. Yogyakarta: Graha Ilmu

Adri, Muhammad. (2008). Strategi Pengembangan Multimedia Intructional Design, diakses pada alamat http://www.ilmukomputer.com, diakses pada tanggal 30 Juni 2008

Toety, Sukamto.1993. Perencanaan dan Pengembangan Sistem instruksional. Jakarta: Intermedia

Zaeni, Hisyam.2002. Desain pembelajaran. Yogyakarta: CTSD IAIN Sunan Kalijogo

Slameto. 1988. Belajar dan Faktor-faktor yang Mempengaruhi. Jakarta : Rineka Cipta,

Hermawan. 2008. Efektifitas Media Pembelajaran. Hermawan01's Weblog

Saragih, HP. 2007. Belajar Tak lagi Membosankan. Sumber : www. wartaekonomi. com (http//detiknas.in/donesia/2007

Arsyad,A.2003.Media Pembelajaran. Jakarta : Raja Grafindo Perkasa. 
Said, A. 2004. Efektifitas CAI terhadap hasil belajar matematika. Jurnal pendidikan Nasional (http//www.depdiknas.go.id/ jurnal)

Rusli Sofian, Muhammad(2005), Rekayasa Pembelajaran Sistem Peredaran darah Berbasis Multimedia untuk Kelas XI, Tesis Magister Komputer. Universitas Dian Nuswantoro.

Syah, Muhibbin. 2002. Psikologi Pendidikan dengan Pendekatan Baru. Bandung : Rosda karya

Djamarah, Syaiful B dan Zain, Aswan. (2002), Strategi Belajar Mengajar. Jakarta : Rineka Cipta

Adri, Muhammad. 2008. Pemanfaatan Teknologi Informasi dalam Pengembangan Media Pembelajaran . Ilmu Komputer . com

Hamalik, Oemar. 1986. Media Pendidikan. Bandung : Penerbit Alumni

Romi Satria Wahono. 2007. Sistem eLearning Berbasis Model Motivasi Komunitas. Jurnal Teknodik No. 21/XI/TEKNODIK/ AGUSTUS/2007

Suyanto, AH. 2005. Mengenal e-Learning. http//www.asep-hs. web.ugm.ac.Id / artikel.

Kadir, Abdul(2003). Dasar Pemrograman Web Dinamis Menggunakan PHP. Yogyakarta : Penerbit Andi.

Dharwiyanti, Sri(2003). Pengantar Unified Modeling Language (UML). http://www.ilmukomputer.com

Raharjo, Suwanto(2007). Testing dan Implementasi Sistem.Band- 
ung: Lab RPL STT Telkom.

Suharsimi. (2001). Dasar Evaluasi Pendidikan. Jakarta : Rineka Cipta Sudjana,(1996). Metode Statistika.Bandung: TarsitoBandung.

Hadi, Sutrisno. (1986). Statistik 2. Yogyakarta : Andi Offset

Suharsimi. (1998). Prosedur Penelitian. Jakarta : Rineka Cipta 